\title{
Sympozjum biblijne Biblia Księgq Wiary (IV edycja), Lwów-Brzuchowice, 25 marca 2017
}

\author{
ks. Stanisław Wronka \\ Uniwersytet Papieski Jana Pawła II w Krakowie \\ stanislaw.wronka@upjp2.edu.pl (D) https://orcid.org/0000-0003-1582-8540
}

Już po raz czwarty w budynku Instytutu Teologicznego im. św. Józefa Bilczewskiego we Lwowie-Brzuchowicach odbyło się sympozjum biblijne z cyklu Biblia Księgą Wiary. Zostało ono zorganizowane przez wspomniany instytut (który jest filią Wydziału Teologicznego Katolickiego Uniwersytetu Lubelskiego Jana Pawła II), Wydział Teologiczny Uniwersytetu Papieskiego Jana Pawła II w Krakowie oraz Dzieło Biblijne Diecezji Radomskiej. Sympozjum odbyło się przed południem 25 marca 2017 roku. Uczestniczyli w nim klerycy Wyższego Seminarium Duchownego Archidiecezji Lwowskiej obrządku łacińskiego oraz studenci Instytutu Teologicznego. Obrady prowadził dyrektor instytutu ks. dr Jacek Uliasz.

W programie przewidziano sześć referatów przygotowanych przez polskich biblistów z Krakowa i Radomia oraz ojca karmelitę pracującego w Archidiecezji Lwowskiej. Ks. prof. dr hab. Tomasz Jelonek (Uniwersytet Papieski Jana Pawła II w Krakowie i Instytut Teologiczny w Brzuchowicach) przedstawił referat Jeden czy dwa opisy stworzenia świata? Jego zdaniem drugi opis biblijny początków (Rdz 2, 4b-25) opowiada raczej o przetwarzaniu uczynionego wcześniej nieba i ziemi oraz koncentruje się na człowieku. Autor biblijny nie używa tutaj czasownika czenie czynności stwarzania. Warto zauważyć, że literatura pozabiblijna nie zna w ogóle pojęcia stwarzania. Ks. dr hab. Stanisław Wronka (Uniwersytet Papieski Jana Pawła II w Krakowie) mówił na temat Dialogu Hioba z Bogiem. W obliczu nieszczęść, które spadły na bohatera księgi, szuka on rozpaczliwie sprawiedliwości Boga, w którego wierzy pomimo wszystko i który na koniec uspokaja jego serce. Hiob jest przykładem bezinteresownej, wytrwałej miłości człowieka do Boga. Z kolei w nawiązaniu do hasła roku duszpasterskiego 2016/2017 w Kościele w Polsce „Idźcie i głoście” dr inż. Anna Maria Wajda (Uniwersytet Papieski Jana Pawła II w Krakowie) omówiła Czynniki sprzyjające 
ewangelizacji w pierwszym wieku ery chrześcijańskiej. Zaliczyła do nich pax romana i ustaloną administrację rzymską, imponującą sieć dróg lądowych (tu Rzymianie czerpali z doświadczenia Persów) i morskich, rozpowszechniony język grecki кoıvń i system pocztowy. Zaistniała sytuacja w basenie Morza Śródziemnego ułatwiła uczniom Pana Jezusa, zwłaszcza św. Pawłowi, dotarcie z Ewangelią do różnych narodów.

Po przerwie mgr Roman Potykiewicz, bibliotekarz Instytutu Teologicznego, odczytał tekst Bóg jako uzdrowiciel w Starym Testamencie przygotowany przez o. dr. Janusza Jankowiaka OCarm (Instytut Teologiczny w Brzuchowicach), który nie mógł przybyć na sympozjum. Księgi Starego Testamentu ukazują Boga jako Stwórcę, Ojca, Króla..., a także jako tego, który leczy (רְָָāpā’) człowieka i narody fizycznie i duchowo. Niekiedy, aby zostać uzdrowionym, człowiek musi spełnić pewne warunki, najczęściej podjąć modlitwę i pokutę. Następnie ks. dr hab. Bogdan Zbroja (Uniwersytet Papieski Jana Pawła II w Krakowie) wygłosił referat Teologia heterogenicznych ksiag $w$ Apokalipsie. Przedstawił w nim pięć różnych ksiąg (oznaczanych terminami: $\beta i ́ \beta \lambda o \varsigma, \beta \iota \beta \lambda i ́ o v, \beta \iota \beta \lambda \alpha \rho i ́ \delta ı v)$ ): księgę Jana, księgę Baranka, księgę w ręku anioła, księgę życia i księgę czynów. Tylko tę ostatnią człowiek zapisuje sam. Po nim mgr Roman Potykiewicz odczytał kolejny tekst pod nieobecność jego autora ks. dr. Jacka Kucharskiego (Wyższe Seminarium Duchowne i Dzieło Biblijne Diecezji Radomskiej) - Kim są kobiety idace za Jezusem: zwolenniczkami, zamożnymi opiekunkami czy uczennicami? Próba identyfikacji na podstawie Łk 8, 1-3. Autor skłania się ku tezie, że kobiety te pełnią wszystkie wymienione role. Jezus uwolnił je od zła i wbrew ówczesnym zwyczajom pozwolił im przebywać w swoim otoczeniu. Po krótkich dopowiedzeniach ks. prof. Tomasza Jelonka dotyczących kobiet towarzyszących Jezusowi oraz kwestii podjętych w Księdze Hioba ks. dr Jacek Uliasz zamknął obrady.

Sympozjum zostało zakończone mszą świętą z uroczystości Zwiastowania Pańskiego, której przewodniczył ks. prof. Tomasz Jelonek. W homilii podkreślił wiarę Maryi, która przyjęła zaproszenie Boga do współpracy w dziele odkupienia, wydając na świat Jezusa i towarzysząc Mu w Jego misji. Przez swoje życie, śmierć i zmartwychwstanie Jezus odnowił stworzenie, zasypał przepaść między człowiekiem i Bogiem uczynioną przez grzech. Maryja nie zawsze wszystko rozumiała, w czym uczestniczyła, ale mądrze i mężnie kroczyła w pielgrzymce wiary, w której nam przewodzi. Ukazuje też najwyższe powołanie kobiety, przewyższające wszystkie inne - powołanie do rodzenia dobra. 
Wyrazem gościnności i wdzięczności Księdza Dyrektora dla prelegentów była jego serdeczna opieka oraz zaproszenie do Opery Lwowskiej na jedną z najlepszych oper klasyka wiedeńskiego Wolfganga Amadeusza Mozarta Don Żuan. Dokładny tytuł opery złożonej z dwóch aktów brzmi: Il dissoluto punito ossia il Don Giovanni [Rozpustnik ukarany, czyli Don Giovanni]. Autorem libretta jest Lorenzo Da Ponte na podstawie dzieła Moliera Don Juan. Ten dramatyczny, choć niepozbawiony też elementów komicznych utwór muzyczny dobrze wpisał się w charakter wielkiego postu, przypominając każdemu, że „jakie życie, taka śmierć”. 